\title{
Physical restraint and the protection of the human rights of immigration detainees in hospitals
}

\author{
Authors: Hilary Pickles, ${ }^{A}$ Emma Norton, ${ }^{B}$ Emma Ginn ${ }^{C}$ and Theresa Schleicher ${ }^{D}$
}

Immigration detainees, like prisoners, are entitled to the same standard of healthcare as non-detained patients. When hospital attendance or admission is required, the priority for custodial staff (who for purposes of this article we refer to as 'escorts') is to prevent absconding. For that reason, they may wish to use physical restraints, such as handcuffs, and remain with the detainee at all times. This can be degrading for the patient and breach their human rights. Clinicians have professional obligations to all their patients and must object to any restraint methods that risk damaging the patient's right to confidentiality, treatment, health or the therapeutic relationship itself. The starting presumption is that restraints ought not to be used during treatment and only in the most exceptional cases ought escorts to be present during clinical examination or treatment.

KEYWORDS: Restraint, human rights, immigration detainee, confidentiality

\section{Introduction to immigration detention}

Increasing numbers of asylum seekers and other migrants are detained in immigration removal centres (IRCs) in the UK. The majority are male and in their 20s and 30s. Some are exprisoners awaiting deportation, but they will have served their time and the offence may have been for the possession of false documents or another non-violent offence. For immigration detainees, unlike prisoners, deprivation of liberty is not for the purposes of punishment or to protect the public. Immigration detention is administrative in nature - that is, without prior judicial approval and without limit of time. The decision to hold someone in administrative detention is often taken at a junior administrative level. The inevitable result is that a person may be held in an IRC for a considerable period of time. Many detainees are damaged and vulnerable and there are high rates of physical and especially mental illness within IRCs. ${ }^{1}$

Authors: Aretired director of public health, Hillingdon, UK; B ${ }^{\text {B }}$ solicitor, Liberty, London, UK; ' ${ }^{C} \mathrm{CO}$-ordinator, Medical Justice, London, UK;

Dcasework manager, Medical Justice, London, UK

\section{Restraint and its adverse effects}

When attending hospital outside the IRC, handcuffs are the usual method of restraint. The detainee is then attached to the escort by a 'closeting' chain, linking the handcuffs to the escort. $^{2}$ In a public area, it is difficult if not impossible for the uniformed escort and detainee to be inconspicuous, even with a short chain, and as a result, patients have reported intense feelings of humiliation and anguish. Patients have further reported adverse reactions from members of the public who appear fearful and curious. A patient may remain handcuffed to an escort during medical examination or treatment. This has caused acute feelings of distress at having to recount highly personal information to healthcare staff in the presence of non-medically trained escorts. Frank dialogue between patient and doctor will almost certainly be inhibited by their presence. Indeed, we are aware of cases where detainees have refused to attend hospital appointments because of the fear of and humiliation arising from restraint. Prolonged handcuffing can causing bruising and discomfort. For a patient admitted to hospital, restraint may be maintained when sleeping, bathing or even using the toilet. Highly sensitive and personal information has been unlawfully recorded by escorts in their security records, for example details of the timing of bowel movements and other clinical information that ought only to be stored on the medical record. To permit otherwise is a breach of the Data Protection Act 1998 (DPA) as well as the patient's right to privacy pursuant to Article 8 of the European Convention on Human Rights (ECHR) incorporated into domestic law by the Human Rights Act. More generally, for patients with a history of imprisonment and torture or abuse, restraint in this way will be particularly distressing and potentially re-traumatising.

\section{The law}

Article 3 of the ECHR protects a person from torture or inhuman and degrading treatment. ${ }^{3}$ Inhuman treatment or punishment is that which causes intense physical or mental suffering, but is not severe enough to amount to torture. Physical assaults can amount to inhuman treatment if sufficiently serious, as can deliberately cruel treatment. Degrading treatment or punishment arouses a feeling of fear, anguish and inferiority, and humiliates and debases the victim. Whether the treatment or punishment is degrading is subjective; where it is sufficient for the victim to feel 


\section{Box 1. The case of FGP. 5}

Eight-day hospital admission in private room on sixth floor.

$>$ Handcuffed throughout, either attached to the escort or to the bed when asleep.

> Second escort present throughout.

> Escorts present during medical assessments, consultations, treatments, showering and toileting.

Sleep disturbed by presence of escorts.

> Intimate clinical details recorded in escorts' notebooks.

Clinicians did not question or challenge use of restraints.

Clinicians did not question or challenge presence of escorts.

> Although restraint had been justified at earlier shorter hospital stays, the Court found FGP was 'humiliated and so degraded' this time by this treatment that it constituted a violation of Article 3 , with the employer of the custody staff guilty of inhuman and degrading treatment.

humiliated, even if that was not the intention of the state agent and s/he does not perceive the treatment as humiliating him/ herself. Handcuffing per se will not amount to a violation of Article 3, however using force on someone deprived of their liberty will violate Article 3 unless strictly necessary. ${ }^{4}$ The courts have held that there is a presumption that restraints should not be applied to detainees during treatment and there should be no attendance of escorts within earshot during consultations unless it is decided on proper grounds that such restraints or presence are needed. ${ }^{5}$ The courts have found that it is not correct to approach the matter on the basis that restraints and presence of escorts will continue unless medical staff request otherwise. In addition, the right to privacy (as enshrined in Article 8 as well as the DPA) may be engaged and breached if the presence of escorts is a disproportionate measure, or if sensitive information has been inappropriately recorded or shared. This does not mean that restraints and the presence of escorts can never be justified. The point is that their presence must be justified on the basis of the individual facts.

\section{The judgment on FGP}

$\mathrm{FGP}^{5}$ (Box 1), an immigration detainee, was admitted to hospital for a period of eight days in 2010. He was handcuffed and attached to an escort by a closeting chain throughout, with a second escort in constant attendance. At no point did the hospital clinicians ask for the handcuffs to be removed, the escorts to step out of the room, or record in the clinical notes that restraints were used. The impact on FGP was very serious and the High Court found the private security company concerned, SERCO plc, responsible for violating FGP's Article 3 rights.

\section{The current guidance}

All patients in the NHS are entitled to be treated equally and to the same high standard. Patients who are subject to detention have the same right to respect, dignity and, except in the most exceptional cases, confidentiality. When on healthcare premises, if escorted, such escorting should be minimal and as inconspicuous as possible. Only in the most exceptional cases ought practitioners to tolerate the presence of escorts in the examination room or during treatment. ${ }^{6}$ The Home Office's official position is that, if requested by a medical practitioner, handcuffs ought to be removed and the medical consultation conducted in private. ${ }^{7}$ However, that is not an accurate reflection of the law, which starts from the presumption that handcuffs ought not to be applied during medical treatment and, only if justified on the basis of a thorough risk assessment, ought they to be used. In any case, health professionals are under a duty to prevent harm to their patients to the best of their abilities. Since handcuffing can cause mental and physical harm, a case may always be made for their removal. So regardless of the state of the law or the escort's understanding of it, it is always incumbent upon the doctors to request removal of restraints, and if refused, request reasons.

The advice from professional bodies concerning restraint does not address the detainee situation directly. Royal College of Nursing guidance is weighted towards the patient who is at risk of harm to themselves and so may need restraining so as not to disrupt essential healthcare interventions. ${ }^{8}$ The British Medical Association guidance focuses on the management of patients who are serving prisoners and who may be a risk to the public. Again, there is a presumption that prisoners are examined or treated without restraints and without prison officers present, preferably in a secure side room. However, continued restraint is possible after dialogue between healthcare and prison for prisoners assessed as high risk of violence, hostage taking or escape. ${ }^{9}$ This is different from the risk assessments of immigration detainees, most of whom have no violent offending history (or indeed any offending history at all) and none of whom will be serving prison sentences at the time of their restraint in any event.

Prior to a decision to restrain with handcuffs, the detainee should be the subject of a risk assessment to determine what level of security is required ${ }^{2}$. In our experience, such risk assessments can be cursory and do not reflect what the law requires. Numerous adverse reports concerning the practice of restraint and the inadequacy of these risks assessments have been made by official inspectorates and non-governmental organisations. ${ }^{10-14}$ In practice, handcuffing appears to be routine.

The standing guidance recommends dialogue when there is disagreement between custodial and health staff, but this is inhibited by confidentiality about the rationale for the patient's risk assessment on one hand and the clinical details on the other. The guidance also recommends escalation to a more senior level where agreement cannot be reached. This however does not address confidentiality concerns and creates delays that can disrupt much needed clinical care.

\section{Good practice moving forward}

Medical staff should not accept without question the views of escorts that detainee patients need to be restrained. If a patient is handcuffed or chained to an escort during medical consultations or treatment, medical staff should be encouraged to request the reason for the restraint and to challenge it, recalling that risk assessments often appear to overstate the risk 
Box 2. Key messages for health professionals.

$>$ Handcuffs and related restraints can be damaging to physical and especially mental health

> Unless strictly necessary, handcuffing a patient may constitute degrading treatment in breach of Article 3 of the European Convention on Human Rights and will always engage the patient's right to privacy

> The professional and legal obligations on clinicians require them to object to the restraint of their patients and to the presence of custody staff during clinical encounters

> Minor adaptations to healthcare premises may be able to satisfy all parties and minimise any risk of absconding

> Any use of restraints on healthcare premises must always be fully justified and recorded in the clinical notes

of absconding. ${ }^{15}$ Even in cases where there is an appreciable risk of absconding, it should be possible to ensure privacy for the clinical encounters by using suitable premises. For those hospitals routinely accepting detained patients, certain consulting and patient rooms can be made secure - windows can be secured with additional locks and escorts posted outside the door. Exactly such arrangements had been made by another department in an isolated block on the ground floor of the same hospital where FGP was treated. The relevant physician had insisted on securing the privacy of his patients and he refused to see his patients with escorts present. Alternatives to restraint will usually be available except in the most exceptional circumstances. As long as escort staff are outside the door and the room is secure, it is hard to see what reasonable justification there can be for restraint, particularly for immigration detainees who are not serving prisoners. The FGP case contains important lessons for medical practitioners and escorts. Similar but not identical issues also arise when serving prisoners are escorted to external NHS healthcare appointments. ${ }^{9,16}$

The practice of restraining women during childbirth is no longer tolerated. More progress is needed to ensure that other detainees undergoing healthcare treatment are similarly protected from abuse. A responsible clinician is obliged to object to restraint and the presence of escorts during confidential consultations. Such objections should be recorded in the medical notes (Box 2).

A concordat between the new NHS health commissioners and the providers of immigration detention services about the use of restraint during healthcare, agreed with the professions and representatives of detainees and NHS providers, could set out best practice and the legal and ethical principles to apply.

\section{References}

1 Robjant K, Hassan R, Katona C. Mental health implications of detaining asylum seekers: a systematic review. Br J Psychiatry 2009;194:306-12.

2 Home Office. Detention Services Order 06/2014. Risk assessment guidance for escorted moves - all contractors on. London: Home Office, 2014. Available online at www.gov.uk/government/publications/risk-assessment-guidance-for-escorted-moves [Accessed 13 May 2015].
3 European Court of Human Rights. European convention on human rights. Strasbourg: European Court of Human Rights. Available online at www.echr.coe.int/Documents/Convention_ENG.pdf [Access 1 July 2015].

4 Selmouni v France (2000) 29 EHRR 403 at [99].

5 FGP v Serco PLC and SSHD [2012] EWHC 1804 (Admin) 05 July 2012.

6 General Medical Council. Good medical practice. London: GMC, 2013. Available online at www.gmc-uk.org/guidance/good_medical_ practice.asp [Accessed 1 July 2015].

7 Council of Europe. Response of the government of the UK to the report of the European Committee for the Prevention of Torture and Inhuman and Degrading treatment or Punishment (CPT) on its visit to the United Kingdom from 17 to 28 September 2012. Strasbourg: Council of Europe, 2014. Available online at www. cpt.coe.int/documents/gbr/2014-12-inf-eng.pdf [Accessed 13 May 2015].

8 Royal College of Nursing. Let's talk about restraint. Rights, risks and responsibility. London: Royal College of Nursing, 2008. Available online at www.rcn.org.uk/_data/assets/pdf_ file/0007/157723/003208.pdf [Accessed 13 May 2015].

9 British Medical Association. Custodial settings: the medical role in restraint and control. London: BMA, 2009. Available online at http://bma.org.uk/-/media/Files/PDFs/Practical\%20advice\%20 at\%20work/Ethics/medicalrolerestraintaug2009.pdf [Accessed 13 May 2015].

10 HM Chief Inspector of Prisons. Report on an unannounced full follow-up inspection of Harmondsworth Immigration Removal Centre. London: Her Majesty's Inspectorate of Prisons, 2012. Available online at www.justiceinspectorates.gov.uk/prisons/wpcontent/uploads/sites/4/2014/03/harmondsworth-2011.pdf [Accessed 1 July 2015].

11 HM Chief Inspector of Prisons. Report on an announced full follow-up inspection of Tinsley House Immigration Removal Centre. London: Her Majesty's Inspectorate of Prisons, 2012. Available online at www.justiceinspectorates.gov.uk/prisons/wpcontent/uploads/sites/4/2014/03/tinsley-house-2012.pdf [Accessed 1 July 2015].

12 Prisons and Probation Ombudsman. Fatal Incidents investigations issue 2. Restraints. Learning lessons bulletin Feb 2013. Available online at http://www.ppo.gov.uk/wp-content/uploads/2014/07/ LLB_FII_Restraints_web_version.pdf [Accessed 19 June 2015].

13 Council of Europe. Report to the government of the United Kingdom on the visit to the United Kingdom carried out by the European Committee for the Prevention of Torture and Inhuman or Degrading Treatment or Punishment (CPT) from 17 to 28 September 2012. Strasbourg: Council of Europe, 2014. Available online at www.cpt. coe.int/documents/gbr/2014-11-inf-eng.pdf [Accessed 13 May 2015].

14 HM Inspector of Prisons. Report of an unannounced inspection of Harmondsworth Immigration Removal Centre. London: Her Majesty's Inspectorate of Prisons, 2014. Available online at www. justiceinspectorates.gov.uk/prisons/wp-content/uploads/ sites/4/2014/03/harmondsworth-2014.pdf [Accessed 19 June 2015].

15 Bail for Immigration Detainees. The Liberty deficit: long term detention \& bail decision-making. London: BID, 2012. Available online at www.biduk.org/sites/default/files/media/docs/BID\%20report $\% 20$ The\%20Liberty\%20Deficit\%20December\%202012.pdf [Accessed 19 June 2015].

16 R (Graham) v Secretary of State for Justice [2007] EWHC 2940 (Admin).

Address for correspondence: Dr H Pickles, 3 Ducks Walk, Twickenham TW1 2DD, UK.

Email: hilary.pickles@doctors.org.uk 